\title{
Zearalenone Induces Endoplasmic Reticulum Stress and Modulates the Expression of Phase I/II Enzymes in Human Liver Cells
}

\author{
Jee Eun Yoon ${ }^{1}$, Kwang Yong Lee ${ }^{2}$, Jin Sil Seok ${ }^{1}$, Wei Nee Cheng ${ }^{1}$, Hyuk Cheol Kwon ${ }^{1}$, \\ Chang Hee Jeong ${ }^{1}$ and Sung Gu Han ${ }^{1, * \mathbb{D}}$ \\ 1 Toxicology Laboratory, Department of Food Science and Biotechnology of Animal Resources, \\ Konkuk University, Seoul 05029, Korea; jee1512@gmail.com (J.E.Y.); seokjinsil@gmail.com (J.S.S.); \\ herm_es@hotmail.com (W.N.C.); rnjs1024@konkuk.ac.kr (H.C.K.); hello01@konkuk.ac.kr (C.H.J.) \\ 2 R \& D department, Morningbio Co., Ltd., Cheonan 31111, Korea; morningbio@daum.net \\ * Correspondence: hansg@konkuk.ac.kr; Tel.: +82-2-450-0526
}

Received: 12 November 2019; Accepted: 17 December 2019; Published: 18 December 2019

\begin{abstract}
Zearalenone (ZEN) is a mycotoxin produced by Fusarium species; however, its mechanisms of action in human livers have not been fully elucidated. Thus, we investigated the toxic mechanisms of ZEN in human liver cells. HepG2 cells were treated with ZEN $(0-40 \mu \mathrm{g} / \mathrm{mL})$ for up to $24 \mathrm{~h}$. A significant decrease in cell viability was observed after treatment with 20 and $40 \mu \mathrm{g} / \mathrm{mL}$ of ZEN, including a significant increase in apoptosis and reactive oxygen species production. ZEN increased GRP78 and CHOP, and eIF2 $\alpha$ phosphorylation, indicating ER stress; elevated transcription of the autophagy-associated genes, beclin1 and LC3, and translation of LC3; and increased phase I metabolism by increasing PXR and CYP3A4. The protein expression level of CYP3A4 was higher with ZEN treatment up to $20 \mu \mathrm{g} / \mathrm{mL}$, but remained at the control level after treatment with $40 \mu \mathrm{g} / \mathrm{mL}$ ZEN. In phase II metabolism, Nrf2 activation and UGT1A expression were increased with ZEN treatment up to $20 \mu \mathrm{g} / \mathrm{mL}$. Treating cells with an ER stress inhibitor alleviated ZEN-induced cell death and autophagy, and inhibited the expression of phase I/II enzymes. Overall, high ZEN concentrations can modulate the expression of phase I/II enzymes via ER stress and reduced protein levels in human liver cells.
\end{abstract}

Keywords: zearalenone; hepatotoxicity; oxidative stress; ER stress; phase I/II metabolism; apoptosis

Key Contribution: Zearalenone is well known to possess estrogenic effects; however, in this study, we demonstrate that zearalenone also induces oxidative stress, apoptosis, ER stress, and autophagy and decreases phase I/II enzymes in human liver cells.

\section{Introduction}

Zearalenone (ZEN) is a non-steroidal estrogenic mycotoxin from Fusarium species [1]. ZEN contamination is mainly observed in crops such as corn, rice, wheat, and barley, and exposure to this mycotoxin can lead to genotoxicity, teratogenicity, immunotoxicity, and reproductive disorders [2-4]. Although ZEN has been known to induce liver toxicity in cells and animals, there is a lack of toxicological information regarding its detailed mechanisms in human liver cells $[5,6]$.

The liver plays a vital role in detoxifying foreign substances and excreting metabolites from the body [7]. When xenobiotics enter the body, the liver secretes numerous enzymes to convert the xenobiotics into more hydrophilic and polar metabolites [8]. These cellular events are referred to as phase I/II metabolism [8]. In phase I metabolism, cytochrome P450 (CYP) enzymes can catalyze the oxidation of xenobiotics, including mycotoxins [9]. Among the many CYP enzymes, CYP3A4 has a broad substrate 
specificity and is abundant in the human liver and the small intestine [10]. The expression level of CYP3A4 is regulated by the nuclear hormone receptor, pregnane $\mathrm{X}$ receptor (PXR) [10]. The metabolites produced by CYP enzymes activate transcription factors, such as nuclear factor erythroid-derived 2-related factor 2 (Nrf2), and induce phase II enzymes, such as UDP-glucuronosyltransferase (UGT), which transfer hydrophilic conjugates to metabolites [11]. The conjugated metabolites can be easily eliminated from the body through phase III transport, which involves the pumping of xenobiotics out of cells using efflux transporters [12].

During the biotransformation of foreign substances, reactive metabolites generate reactive oxygen species (ROS) in phase I metabolism [13]. ROS is linked to endoplasmic reticulum (ER) stress in cells [14]. The altered redox homeostasis causes the accumulation of misfolded and unfolded proteins in the ER lumen [15]. When ER stress occurs, unfolded protein response is activated to resolve the misfolding and unfolding of proteins [15]. However, when cells cannot overcome ER stress, ER stress-induced cell death is initiated through activated pro-apoptotic pathways [16]. However, to adapt to cellular stress conditions, including ER stress, autophagy can be initiated [17]. Autophagy plays physiological roles in eukaryotic cells, including degradation and recycling of proteins and defective organelles, and these events are mediated by specific molecules, such as microtubule-associated protein $1 \mathrm{~A} / 1 \mathrm{~B}$ light chain 3 (LC3), beclin1, and autophagy-related genes [18].

Although the cytotoxicity of ZEN has been examined in mammalian cells (e.g., mouse Sertoli TM4 cells, porcine oocytes, and human neuroblastoma SH-SY5Y cells), its association with phase I/II metabolism has not been investigated in human liver cells. Therefore, the purpose of this study was to investigate the molecular mechanisms of ZEN-induced hepatotoxicity (i.e., oxidative stress, ER stress, apoptosis, and autophagy) and their association with phase I/II metabolism in human liver cells.

\section{Results}

\subsection{ZEN-Induced Cytotoxicity in Human Liver Cells}

After cells were treated with ZEN $(0,1,5,10,20$, and $40 \mu \mathrm{g} / \mathrm{mL})$ for $24 \mathrm{~h}$, the cytotoxic effect of ZEN on HepG2 cells was examined using the trypan blue dye exclusion test. Based on the results, ZEN significantly decreased cell viability at 20 and $40 \mu \mathrm{g} / \mathrm{mL}$, compared to the control (Figure 1). However, a marked difference in cell numbers was not observed with ZEN treatment up to $10 \mu \mathrm{g} / \mathrm{mL}$.

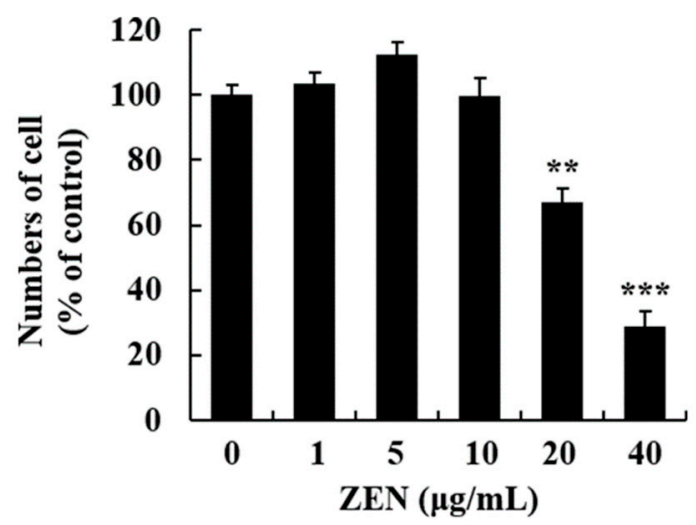

Figure 1. Zearalenone (ZEN) induced cytotoxicity in HepG2 cells. Cells were treated with ZEN (0, 1, 5, 10,20 , and $40 \mu \mathrm{g} / \mathrm{mL}$ ) for $24 \mathrm{~h}$ and cell viability was measured by the trypan blue dye exclusion test. Data represent mean \pm SEM of three independent experiments. ${ }^{*}$ indicates significant difference vs. the control $\left({ }^{* *} p<0.01\right.$, and $\left.{ }^{* * *} p<0.001\right)$.

\subsection{ZEN Increased Apoptosis in Human Liver Cells}

The ratio of apoptotic cells was measured using an Annexin V-fluorescein isothiocyanate (FITC)/propidium iodide (PI) double staining assay. The results of flow cytometry analysis revealed 
that the apoptotic rate was significantly increased at 20 and $40 \mu \mathrm{g} / \mathrm{mL}$ of ZEN (Figure 2A,B). Early apoptotic cells were mainly observed with ZEN treatment at $20 \mu \mathrm{g} / \mathrm{mL}$, whereas both early apoptotic and late apoptotic cells were observed with $40 \mu \mathrm{g} / \mathrm{mL}$ (Figure 2A,B). There was no marked difference in the rate of apoptotic cells with ZEN treatment up to $10 \mu \mathrm{g} / \mathrm{mL}$.

$\mathbf{A}$

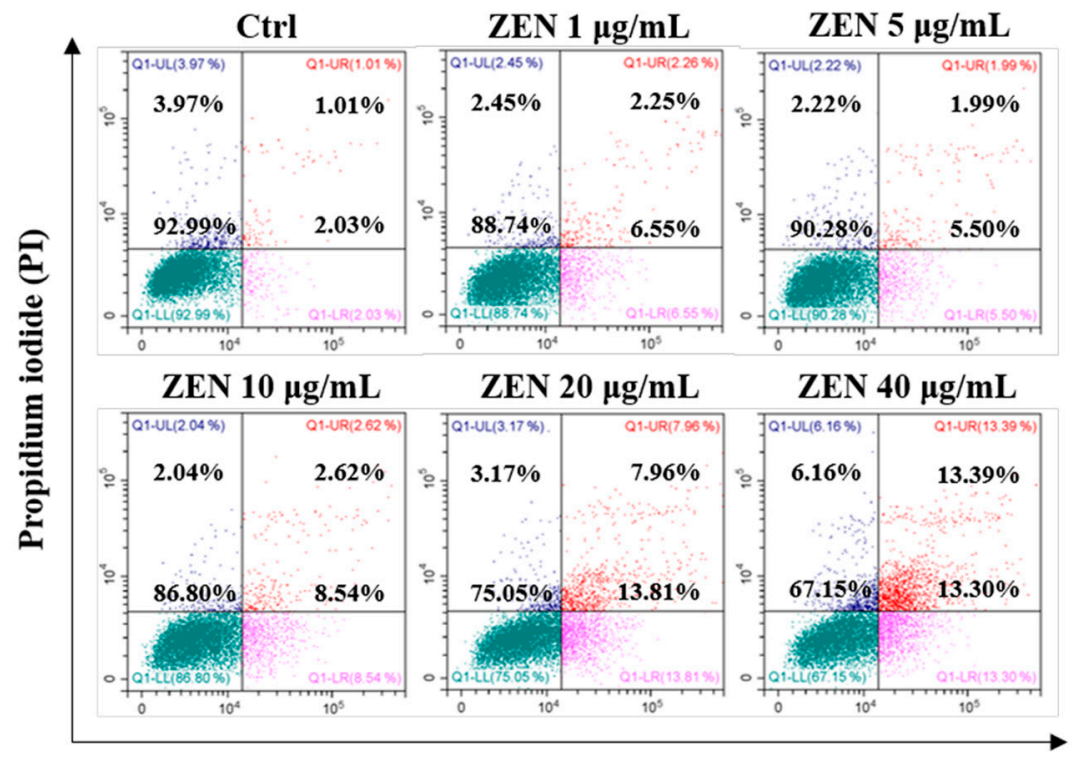

B

Annexin V-fluorescein isothiocyanate (FITC)

Figure 2. Zearalenone (ZEN) induced apoptosis in HepG2 cells. (A) Cells were treated with ZEN $(0,1,5,10,20$, and $40 \mu \mathrm{g} / \mathrm{mL})$ for $24 \mathrm{~h}$ and apoptotic/necrotic cells were analyzed using CytoFLEX flow cytometer after Annexin V-FITC/PI double staining. (B) The apoptotic rate was calculated using CytExpert software (The parts of Annexin V+/PI- and Annexin V+/PI+ represent early apoptotic cells and late apoptotic/necrotic cells, respectively). The images represent three independent experiments. Data represent mean \pm SEM. ${ }^{*}$ indicates significant difference vs. the control $\left({ }^{* *} p<0.01\right.$, and *** $p<0.001)$.

\subsection{ZEN Increased Oxidative Stress, ER Stress, and Autophagy in Human Liver Cells}

To investigate the underlying mechanisms of ZEN-induced toxicity, oxidative stress was measured using the $2^{\prime}, 7^{\prime}$-dichlorofluorescin diacetate (DCFH-DA) and dihydroethidium (DHE) staining techniques. After $2 \mathrm{~h}$ of incubation with ZEN, particularly at 20 and $40 \mu \mathrm{g} / \mathrm{mL}$, cellular ROS (e.g., superoxide anion) production were increased in a dose-dependent manner (Figure 3A-D). The protein expression level of glucose-related protein 78 (GRP78), a marker of ER stress, was also increased at $40 \mu \mathrm{g} / \mathrm{mL}$ of ZEN (Figure $4 \mathrm{~A}$ ). Furthermore, the phosphorylation of eukaryotic initiation factor $2 \alpha(\mathrm{eIF} 2 \alpha)$, an ER stress-related regulator of the initiation of protein translation, was observed after cells were treated with ZEN. ZEN $(40 \mu \mathrm{g} / \mathrm{mL})$ significantly increased the phosphorylation of eIF $2 \alpha$ by approximately 5 -fold relative to the control (Figure $4 \mathrm{~B}$ ). These results suggest that a high concentration of ZEN could inhibit protein synthesis through ER stress.

As ZEN was found to cause ER stress in HepG2 cells, which was demonstrated by the increase in eIF2 $\alpha$ phosphorylation, we analyzed the ER stress-related cell signaling molecules linked to apoptosis and autophagy. The mRNA level of human C/EBP homologous protein (CHOP), which is implicated in apoptosis in response to severe ER stress, was measured by quantitative real-time polymerase chain reaction (qRT-PCR). Based on our findings, the level of CHOP mRNA was significantly increased in ZEN-treated cells, particularly at 10, 20, and $40 \mu \mathrm{g} / \mathrm{mL}$ (Figure 4C). The mRNA levels of beclin1 and LC3-II, the autophagy markers involved in the biogenesis of autophagosome, were markedly increased with 20 and $40 \mu \mathrm{g} / \mathrm{mL}$ of ZEN, compared to control (Figure 4D,E). Furthermore, the protein expression 
level of LC3 was examined by Western blot analysis. As shown in Figure 4F, the LC3-II to LC3-I ratio was significantly increased at $40 \mu \mathrm{g} / \mathrm{mL}$ of ZEN. Such findings indicate that ZEN can induce ER stress, ER stress-induced apoptosis, and autophagy at higher concentrations of ZEN (20 and $40 \mu \mathrm{g} / \mathrm{mL}) \mathrm{in}$ human liver cells.

\section{A}
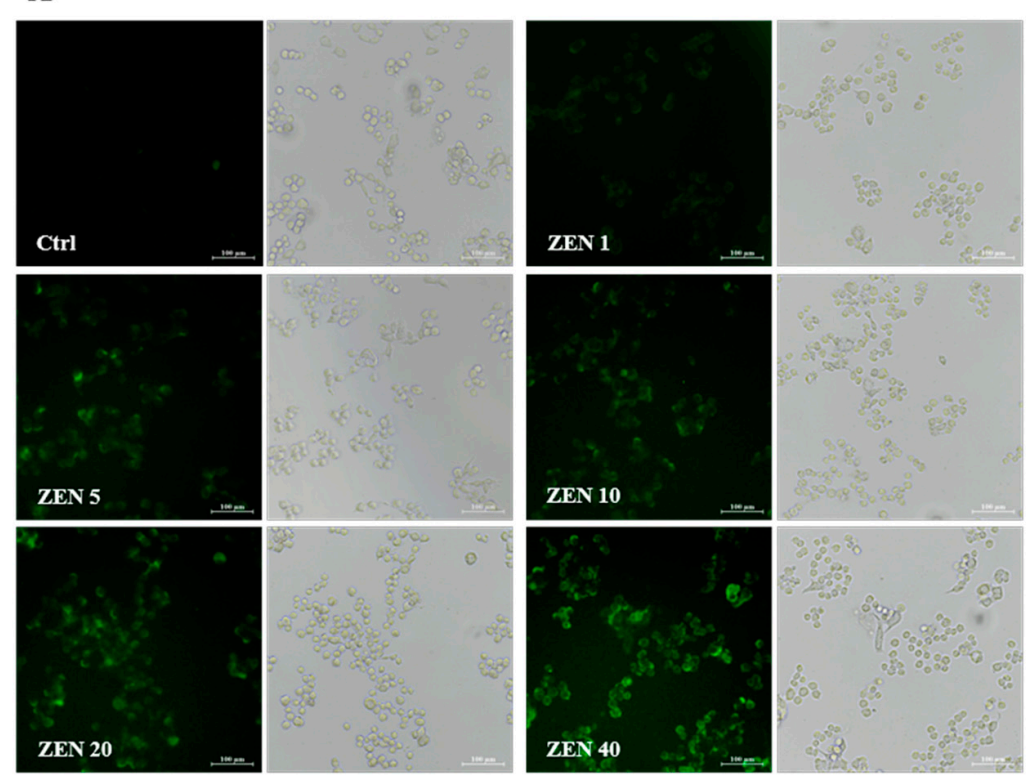

B
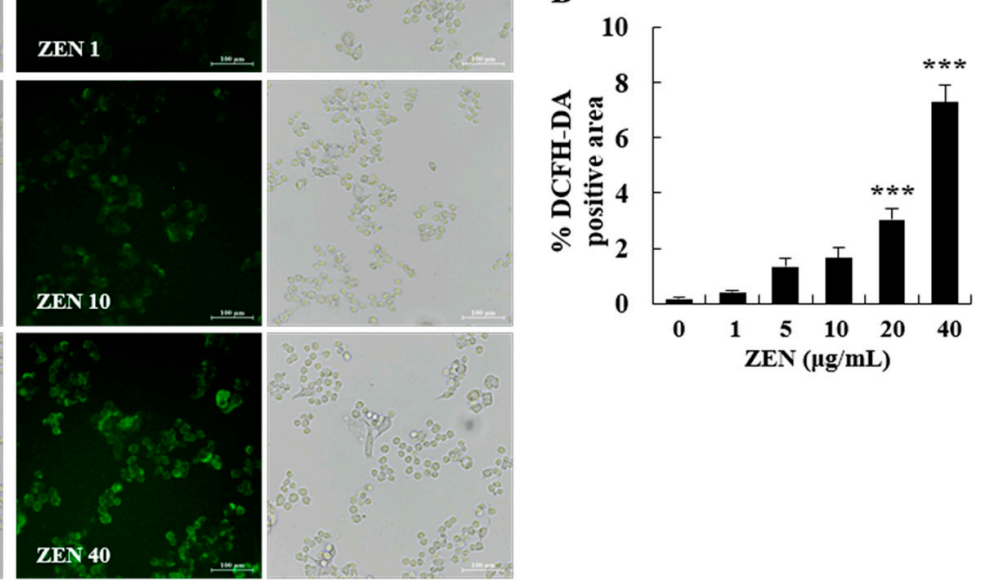

C
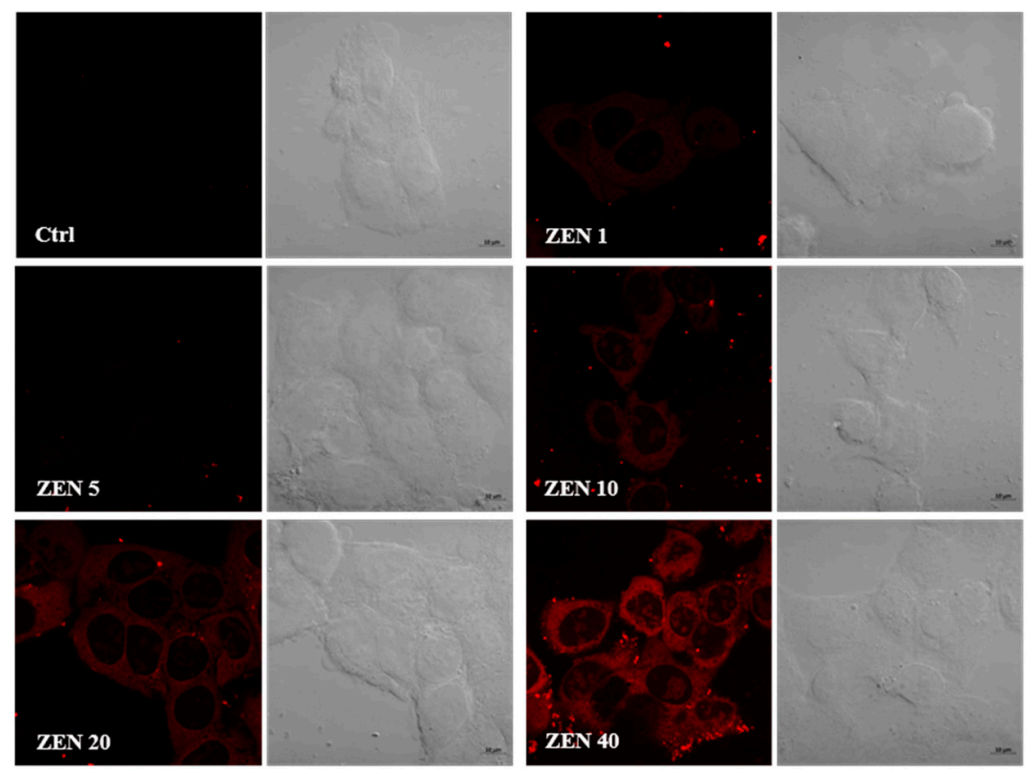

D
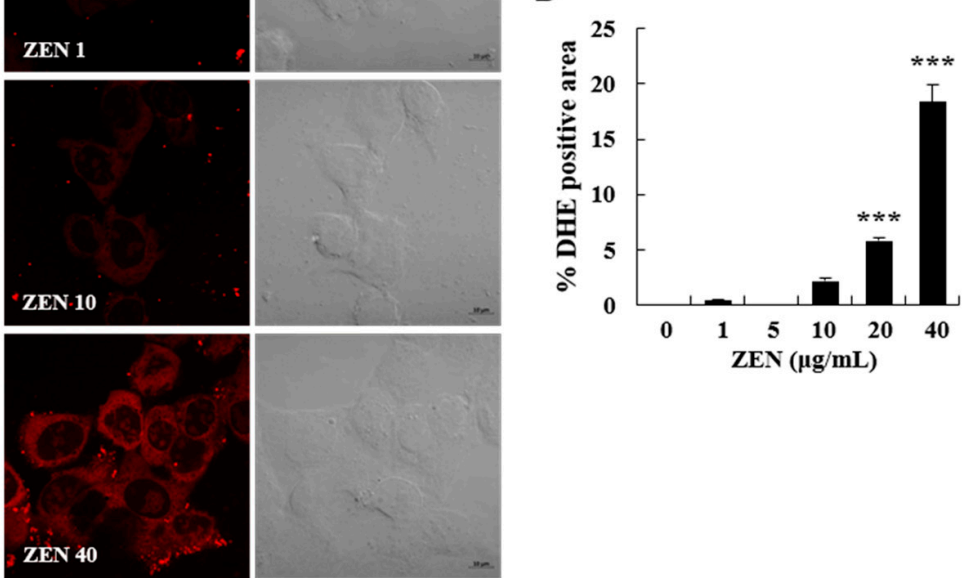

Figure 3. Zearalenone (ZEN) induced oxidative stress in HepG2 cells. Cells treated with ZEN (0, 1, $5,10,20$, and $40 \mu \mathrm{g} / \mathrm{mL}$ ) for $2 \mathrm{~h}$ were stained with (A) $2^{\prime}, 7^{\prime}$-dichlorofluorescin diacetate (DCFH-DA) and (C) dihydroethidium (DHE) to detect intracellular reactive oxygen species (ROS) production. The intensity of green fluorescence (general ROS production) and red fluorescence (superoxide anion production) was assessed by a fluorescence microscope at $200 \times$ magnification and a super-resolution confocal laser scanning microscope at $630 \times$ magnification, respectively. (B) The DCFH-DA positive area (green fluorescence) and (D) DHE positive area (red fluorescence) were analyzed using Image J software and graphically presented. The images shown are representatives of three independent experiments. Data represent mean $\pm \mathrm{SEM}$. * indicates significant difference vs. the control $\left({ }^{* * *} p<0.001\right)$. 
A

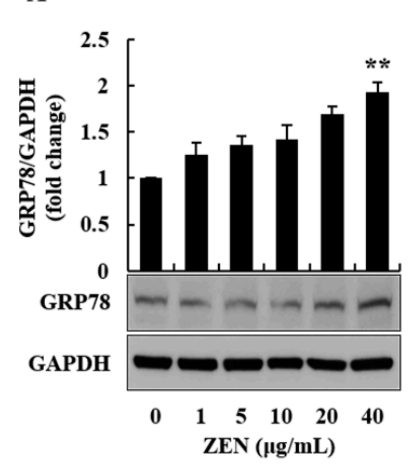

D

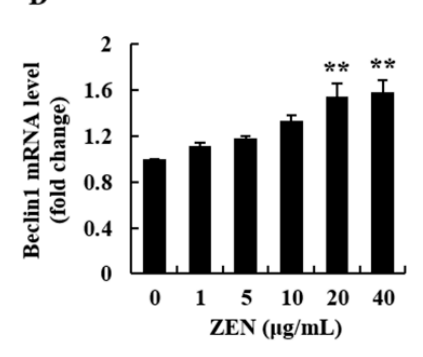

B

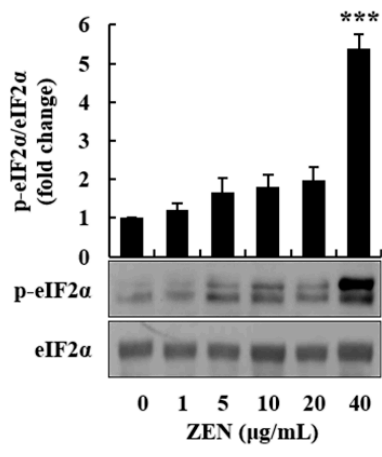

C

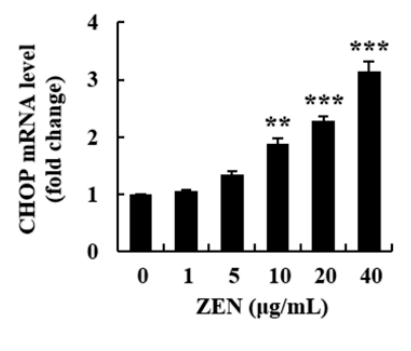

$\mathbf{F}$

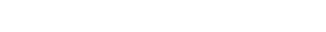

$\mathbf{E}$
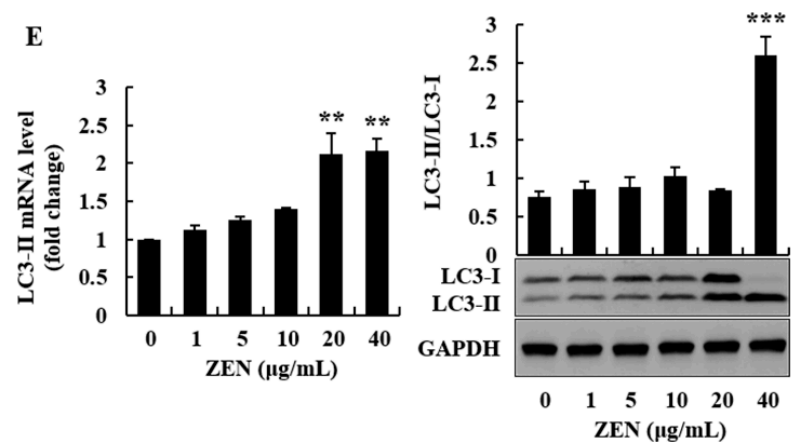

Figure 4. Zearalenone (ZEN) induced endoplasmic reticulum (ER) stress and autophagy in HepG2 cells. mRNA level and protein expression were determined by quantitative real-time polymerase chain reaction (qRT-PCR) and Western blot analysis, respectively. (A) The protein expression level of GRP78 was measured in cells treated with ZEN for $1 \mathrm{~h}$. (B) The phosphorylation of eIF2 $\alpha$ was evaluated in cells treated with ZEN for $2 \mathrm{~h}$. (C) CHOP mRNA levels, (D) Beclin1 mRNA levels, and (E) LC3-II mRNA levels were determined in cells treated with ZEN for $4 \mathrm{~h}$. (F) The protein expression level of LC3-II/LC3-I was examined in cells treated with ZEN for $24 \mathrm{~h}$. Data represent mean \pm SEM of three independent experiments. ${ }^{*}$ indicates significant difference vs. the control $\left({ }^{* *} p<0.01\right.$, and $\left.{ }^{* * *} p<0.001\right)$.

\subsection{ZEN Induced Phase I/II Metabolism and ER Stress Inhibited Phase I/II Metabolism}

As the induction of xenobiotic defense mechanism may be linked to ER stress, we investigated the cellular responses caused by phase I/II metabolism. The mRNA expression of PXR and CYP3A4, and the protein expression of CYP3A4 were evaluated to identify the effects of ZEN on phase I metabolism. As shown in Figure 5A,B, the mRNA expression of PXR and CYP3A4 were increased in a dose-dependent manner. When treated with $40 \mu \mathrm{g} / \mathrm{mL}$ of ZEN, CYP3A4 mRNA expression level was approximately 20-fold higher than when treated with the control. However, through Western blot analysis, the protein expression level of CYP3A4 was increased at 10 and $20 \mu \mathrm{g} / \mathrm{mL}$ of ZEN, but remained at the control level at $40 \mu \mathrm{g} / \mathrm{mL}$ (Figure $5 \mathrm{C}$ ). These data suggest that the observed ER stress (Figure $4 \mathrm{~A}-\mathrm{C}$ ) may result in the inhibition of CYP3A4 protein synthesis at $40 \mu \mathrm{g} / \mathrm{mL}$ of ZEN. This inability of the CYP3A4 mRNA to be translated to protein may result in a decrease in phase I metabolism when a high concentration of ZEN exists in the liver cells over time.

In addition to phase I biotransformation, phase II enzymes are known to metabolize phase I metabolites. Thus, phase II biotransformation-related genes, such as UGT1A, and the activation of the transcription factor, Nrf2, were measured in cells. Translocation of Nrf2 from the cytosol to the nucleus was increased in cells treated with $20 \mu \mathrm{g} / \mathrm{mL}$ of ZEN (Figure 6A). However, the nuclear translocation of Nrf2 returned to control levels at $40 \mu \mathrm{g} / \mathrm{mL}$ of ZEN. Similarly, ZEN increased the mRNA expression of UGT1A up to $20 \mu \mathrm{g} / \mathrm{mL}$; however, there was no significant increase in UGT1A at $40 \mu \mathrm{g} / \mathrm{mL}$ (Figure 6B). Overall, our data demonstrate that the expression level of the phase I/II enzymes was induced up to $20 \mu \mathrm{g} / \mathrm{mL}$ of ZEN but was inhibited at higher concentrations, such as $40 \mu \mathrm{g} / \mathrm{mL}$ of ZEN, in HepG2 cells. 
A

B
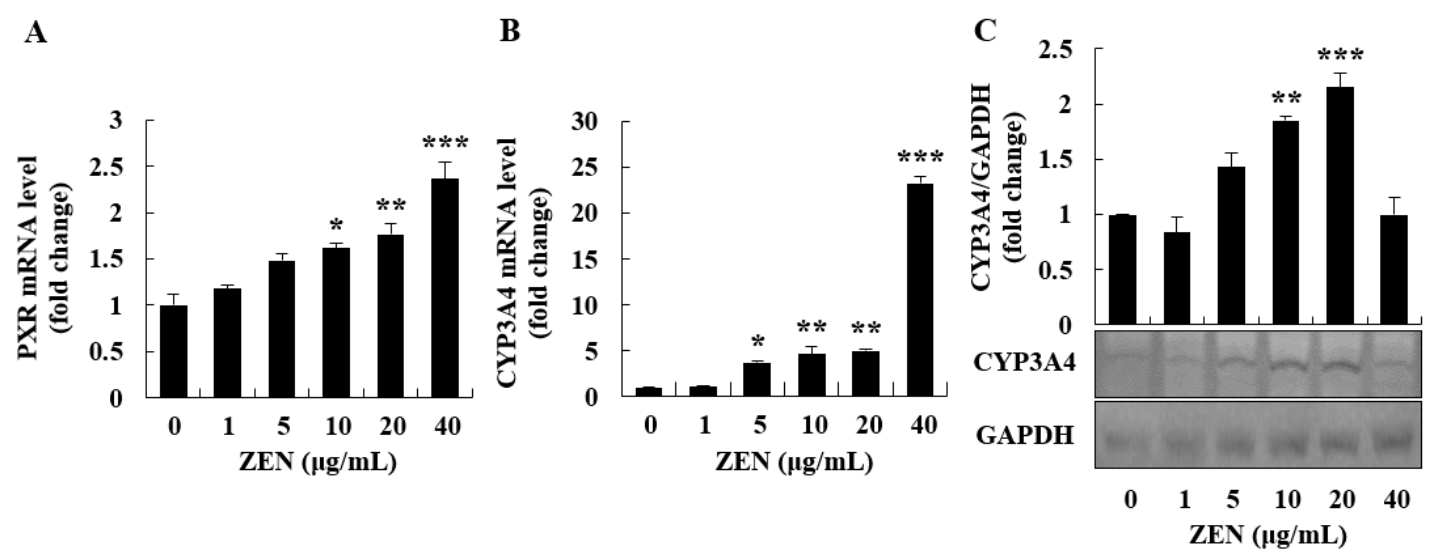

Figure 5. Zearalenone (ZEN) induced the expression of PXR and CYP3A4, and ZEN-induced ER stress inhibited the protein expression of CYP3A4. mRNA level and protein expression were determined by quantitative real-time PCR (qRT-PCR) and Western blot analysis, respectively. (A) PXR mRNA levels were determined in cells treated with ZEN for $4 \mathrm{~h}$. (B) CYP3A4 mRNA levels were determined in cells treated with ZEN for $8 \mathrm{~h}$. (C) The protein expression level of CYP3A4 was examined in cells treated with ZEN for $24 \mathrm{~h}$. Data represent mean \pm SEM of three independent experiments. * indicates significant difference vs. the control $\left({ }^{*} p<0.05\right.$, ${ }^{* *} p<0.01$, and $\left.{ }^{* * *} p<0.001\right)$.

\subsection{4-Phenylbutyric Acid Alleviated ZEN-Induced ER Stress and Autophagy, and Inhibited Phase I/II Metabolism}

To further confirm the role of ER stress in the hepatotoxicity of ZEN, HepG2 cells were treated with the ER stress inhibitor, 4-phenylbutyric acid (4-PBA), prior to ZEN treatment. At a concentration of $1 \mathrm{mM}$, 4-PBA displayed no significant cytotoxicity (Figure 7A). ZEN-induced phosphorylation of eIF2 $\alpha$ and the increase in the LC3-II/LC3-I ratio were significantly attenuated in the presence of 4-PBA, compared to $40 \mu \mathrm{g} / \mathrm{mL}$ of ZEN alone (Figure 7B,C). Furthermore, in the same cell treatment condition, the expression of CYP3A4 and UGT1A was recovered by the ER stress inhibitor (Figure 7D,E). These findings suggest that ZEN-induced autophagy and the inhibition of protein synthesis (CYP3A4 and UGT1A) may be, at least in part, due to the ER stress caused by a high concentration of ZEN $(40 \mu \mathrm{g} / \mathrm{mL})$.

A

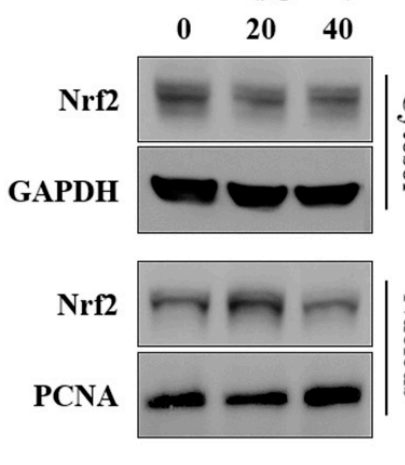

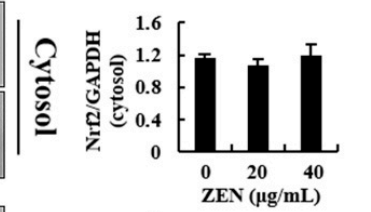

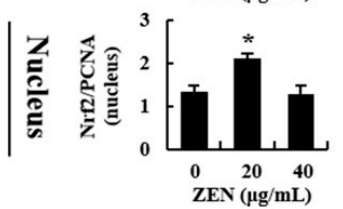

B

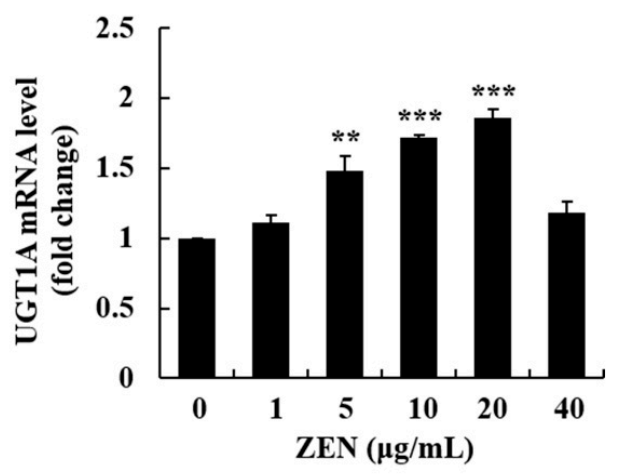

Figure 6. Zearalenone (ZEN) induced Nrf2 activation and UGT1A expression. The mRNA level and protein expression of signaling mediators were determined by quantitative real-time PCR (qRT-PCR) and Western blot analysis, respectively. (A) Nrf2 nuclear translocation was measured in cells treated with ZEN (20 and $40 \mu \mathrm{g} / \mathrm{mL}$ ) for $6 \mathrm{~h}$ by nuclear fractionation and Western blotting. (B) UGT1A mRNA levels were determined in cells treated with ZEN for $16 \mathrm{~h}$. Data represent mean \pm SEM of three independent experiments. ${ }^{*}$ indicates significant difference vs. the control $\left({ }^{*} p<0.05,{ }^{* *} p<0.01\right.$, and $* * * p<0.001)$. 
B
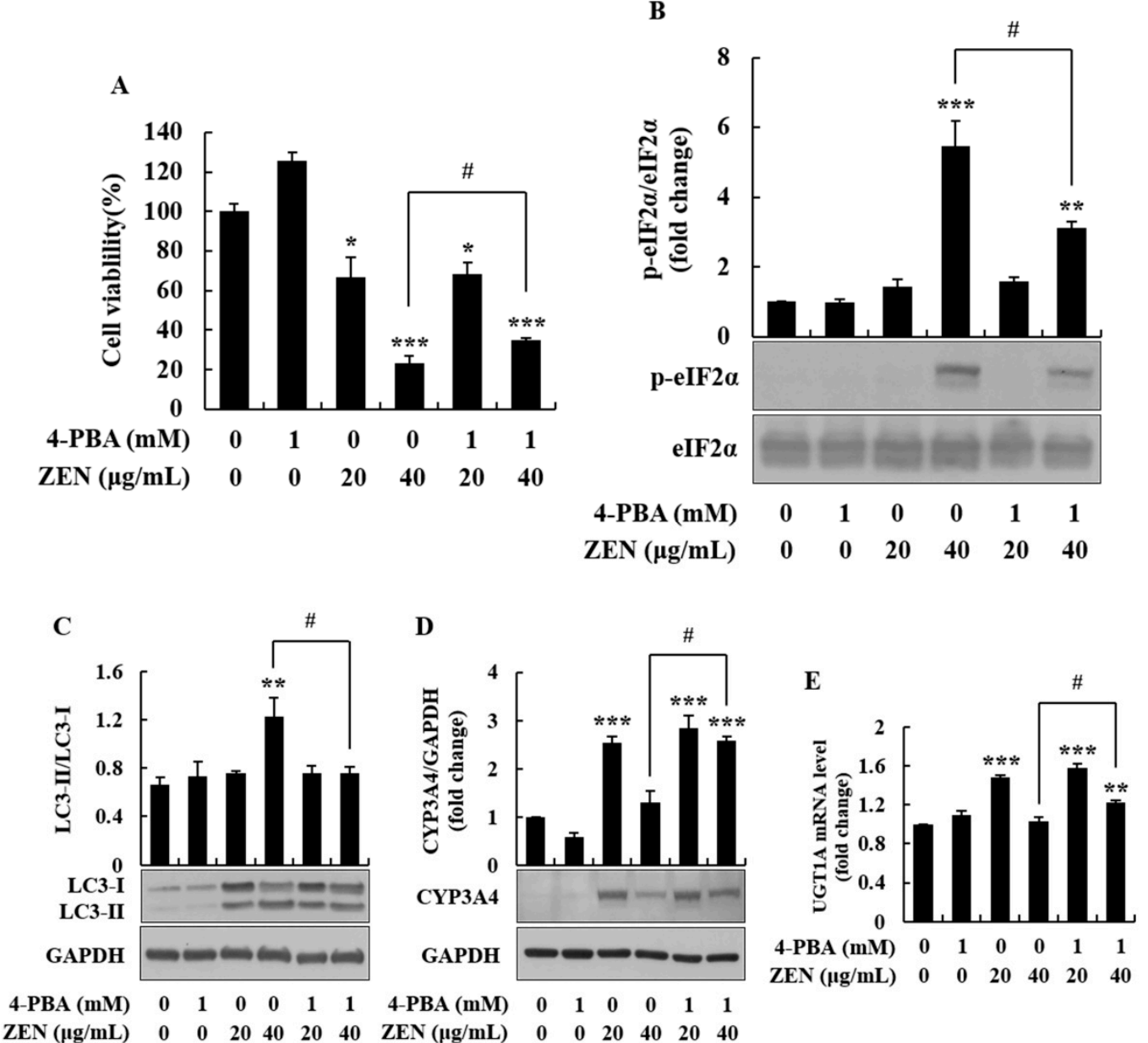

Figure 7. 4-phenylbutyric acid (4-PBA) alleviated zearalenone (ZEN)-induced ER stress, autophagy, and downregulation of CYP3A4 and UGT1A. Before treatment with ZEN (20 and $40 \mu \mathrm{g} / \mathrm{mL})$, cells were pretreated with $1 \mathrm{mM} 4$-PBA for $6 \mathrm{~h}$. mRNA and protein expression were determined by quantitative real-time PCR (qRT-PCR) and Western blot analysis, respectively. (A) Cells were treated with ZEN for $24 \mathrm{~h}$ after pretreatment with 4-PBA and cell viability was measured by the trypan blue dye exclusion test. (B) Phosphorylation of eIF2 $\alpha$ was evaluated in cells treated with ZEN for $2 \mathrm{~h}$. The protein expression of (C) LC3-II/LC3-I and (D) CYP3A4 was determined in cells treated with ZEN for $24 \mathrm{~h}$. (E) UGT1A mRNA levels were determined in cells treated with ZEN for $16 \mathrm{~h}$. Data represent mean \pm SEM of three independent experiments. ${ }^{*}$ indicates significant difference vs. the control $\left({ }^{*} p<0.05,{ }^{* *} p<0.01\right.$, and *** $p<0.001)$. \# indicates significant difference between groups $(p<0.05)$.

\section{Discussion}

Mycotoxins are toxic secondary metabolites biosynthesized by fungi [19]. Contamination of foods and feedstuffs with mycotoxins not only results in economic losses but also severe health problems in humans and farm animals [20]. Consumption of mycotoxin-contaminated products can lead to mycotoxicosis and accompanying acute or chronic symptoms. These products are carcinogenic, hepatotoxic, immunosuppressive, and teratogenic [21]. Among many mycotoxins, ZEN is well known to possess an estrogenic effect; however, liver toxicity and the detailed mechanisms underlying this effect have not been fully understood. Thus, in the current study, hepatotoxicity and its related molecular pathways were investigated using the human liver cell line, HepG2.

To determine the effects of ZEN on cell viability, we employed the trypan blue dye exclusion test. Based on the results, cell viability was markedly lower in cells treated with 20 and $40 \mu \mathrm{g} / \mathrm{mL}$ of ZEN. To identify the cellular mechanism of ZEN-induced cell death, apoptosis was measured. The apoptosis level was markedly increased at 20 and $40 \mu \mathrm{g} / \mathrm{mL}$, which indicates that early apoptosis may be a major 
mechanism in cells treated with a low dose $(20 \mu \mathrm{g} / \mathrm{mL})$ of ZEN. However, both apoptosis and necrosis occurred when a high dose of ZEN ( $40 \mu \mathrm{g} / \mathrm{mL})$ was administered. These results align with those of previous findings wherein the high dose of ZEN predominantly caused late apoptosis and necrosis compared to the low dose in mouse RAW 264.7 macrophages [22,23]. As oxidative stress is frequently involved in cytotoxicity and cell death, the level of ROS was measured using the DCFH-DA and DHE staining methods. As expected, ZEN induced a significant increase in ROS production (e.g., superoxide anion) at 20 and $40 \mu \mathrm{g} / \mathrm{mL}$. These data suggest that cellular oxidative stress plays a critical role in the observed apoptosis. In previous studies, similar results were observed in HepG2 and porcine IPEC-J2 cells as ZEN generated ROS, reduced antioxidant enzyme activities, and induced cell death in vitro [24-26].

Cellular oxidative stress is known to induce ER stress [27]. Because ROS production was highly increased in ZEN-induced cells, particularly at 20 and $40 \mu \mathrm{g} / \mathrm{mL}$, the ER stress-related markers, GRP78 and phosphorylated eIF2 $\alpha$, were measured via Western blot analysis. ZEN increased the expression of GRP78 and the phosphorylation of eIF2 $\alpha$ at 5, 10, 20, and $40 \mu \mathrm{g} / \mathrm{mL}$. In particular, a high concentration of ZEN $(40 \mu \mathrm{g} / \mathrm{mL})$ significantly increased the expression of GRP78 and phosphorylated eIF2 $\alpha$. GRP78 is a master regulator of unfolded protein response that interacts with three ER stress sensors, including protein kinase RNA-like endoplasmic reticulum kinase (PERK) [28]. Upon ER stress, GRP78 is released from the sensors, resulting in eIF2 $\alpha$ phosphorylation through PERK, followed by the global inhibition of protein synthesis [29]. Previously, phosphorylation of eIF $2 \alpha$ and inhibition of protein synthesis were found to increase the number of apoptotic cells [30]. A past study also reported that excessive superoxide generation at the ER led to ER stress and apoptosis [31]. In fact, ZEN increased ROS level in lymphocytes that led to excessive oxidative modification of proteins, ER stress and apoptosis [32]. Therefore, our findings regarding ZEN-induced apoptotic cells may be due to ER stress. Previously, ER stress was implicated in apoptosis through CHOP, a downstream signaling molecule of eIF2 $\alpha$ [33]. Transcriptional activation of CHOP plays an important role in ER stress-induced apoptosis in cells [34]. Furthermore, a prior study reported similar data in human colon HCT116 cells and human kidney HEK293 cells [35]. In this cell culture study, ZEN induced ER stress and ER stress-mediated cell death through the CHOP pathway. Overall, our findings demonstrate that ER stress, CHOP expression, and apoptosis are important adverse cellular signaling pathways in ZEN-exposed human liver cells.

Under stress conditions, the ER responds to stimuli through translational attenuation and upregulation of protein folding capacity [15]. ER stress can also trigger autophagy via the PERK/eIF2 $\alpha$ pathway [36]. Autophagy is a catabolic system characterized by sequestration of cytoplasmic organelles and proteins through autophagosomes/lysosomes. In the current study, ZEN increased both autophagy-associated genes, such as beclin1 and LC3-II, at 20 and $40 \mu \mathrm{g} / \mathrm{mL}$, and the ratio of LC3-II/LC3-I protein at $40 \mu \mathrm{g} / \mathrm{mL}$. During the biogenesis of autophagosome, beclin 1 forms a complex with the lipid kinase vacuolar protein sorting 34 (VPS34) and VPS15, thereby driving the nucleation of the isolation membrane [37]. Thereafter, membrane elongation and closure are conducted by two ubiquitin-like conjugation systems, including the LC3 conjugation system, where LC 3 is converted to its membrane-bound form, LC3-II [38]. The completed autophagosome fuses with lysosome via several molecules, including beclin1 and LC3-II, leading to the generation of autolysosome and degradation of the enwrapped cytosolic components [38]. Transcriptional elevation of beclin1 and LC3 has been reported in cells undergoing autophagy. For example, activation of SIRT1 enhanced autophagy by increasing the mRNA levels of beclin1 and LC3 in cells such as murine osteoblast MC3T3-E1 cells and degenerative human disc nucleus pulposus cells [39,40]. Although autophagy is a cellular defense process, overproduction of autophagic vesicles can cause cell death by catabolizing indispensable portions of cells and activating apoptotic/necrotic programs [41]. Therefore, the increase in cell death, which was observed in cells treated with 20 and $40 \mu \mathrm{g} / \mathrm{mL}$ of ZEN, may be at least in part due to the overproduction of autophagic vesicles. Similar to our data, ZEN could induce autophagy by increasing beclin1, LC3-II, and autophagosomes in mouse and rat testicular cells [42,43]. Other potential mechanisms were reported in a recent publication where ZEN could induce the expression of 
cytochrome P450 reductase and oxidative stress, resulting in autophagy in porcine intestinal epithelial cells [44].

After ingestion, the absorbed ZEN is primarily metabolized by hepatocytes and enterocytes [45]. In human liver microsomes, ZEN activates xenosensor molecules such as PXR, followed by monohydroxylation of ZEN by the CYP superfamily [46]. In this detoxification process, ZEN is converted to more hydrophilic molecules [46]. In a previous study, ZEN activated nuclear receptors (e.g., PXR) and their phase I target genes (e.g., CYP3A4) in human primary hepatocytes [47]. In our study, ZEN increased the mRNA levels of PXR and CYP3A4 in a dose-dependent manner, which suggested the activation of phase I metabolism in HepG2 cells. Biphasic dose-response is the low-dose stimulation and high-dose inhibition of certain endpoints when cells are exposed to xenobiotics [48]. Chemicals such as $\alpha$-benzene hexachloride produce a biphasic dose-response in rat hepatocarcinogenesis [48]. In the current study, protein expression of CYP3A4 showed a biphasic dose-response. Through Western blot analysis, its protein expression level was found to be significantly downregulated in cells treated with $40 \mu \mathrm{g} / \mathrm{mL}$ of ZEN, whereas its mRNA levels were dose-dependently increased following treatment with up to $40 \mu \mathrm{g} / \mathrm{mL}$ of ZEN. As the mRNA expression level of CYP3A4 was markedly higher at $40 \mu \mathrm{g} / \mathrm{mL}$, ZEN-induced ER stress was assumed to be associated with the inability to carry out the translational process. These data suggest that the biotransformation process via the CYP enzyme is not actively occurring in cells exposed to a high concentration of ZEN $(40 \mu \mathrm{g} / \mathrm{mL})$. The inability of translation efficiency can be explained by ZEN-induced phosphorylation of eIF2 $\alpha$ as observed in the current study. In fact, once cells experience ER stress, eIF2 $\alpha$, a regulatory subunit of eIF2, is phosphorylated by protein kinases, leading to the global inhibition of protein synthesis [49]. In addition to phase I metabolism, phase II metabolism was investigated. This is because phase I/II metabolism is linked to toxic substances in cellular responses. A prior study reported that ZEN can induce phase II metabolism by upregulating the transcription factor, Nrf2, and its target gene, UGT1A, in piglet liver [50]. Our data, however, showed that ZEN increased phase II metabolism-related molecules, such as the activation of Nrf2 and the mRNA level of UGT1A up to $20 \mu \mathrm{g} / \mathrm{mL}$, but not at $40 \mu \mathrm{g} / \mathrm{mL}$. These results are similar to those for phase I-associated transcription factor and enzymes, such as PXR and CYP3A4. The ER stress initiated by high concentrations of ZEN (i.e., $40 \mu \mathrm{g} / \mathrm{mL}$ ) may be responsible for the decreased expression of phase II metabolism-related molecules (i.e., Nrf2 and UGT1A). Altogether, our findings suggest that a high concentration of ZEN, such as $40 \mu \mathrm{g} / \mathrm{mL}$, can disrupt the normal detoxification processes (phase I/II metabolism) in human liver cells, potentially via ER stress and a decrease in the expression of the phase I/II enzymes.

4-PBA is a hydrophobic short chain fatty acid that is utilized as an ER stress inhibitor [51]. As a chemical chaperone, 4-PBA interacts with the hydrophobic domains of unfolded proteins and prevents their aggregation to improve protein folding and stability [51]. Previous studies have reported that 4-PBA reduces ER stress and inhibits ER stress-related markers, including p-eIF2 $\alpha$ [52-54]. In the current study, 4-PBA could ameliorate ZEN-induced cell death and autophagy, and increase the expression of phase I/II enzymes by decreasing ER stress. These data suggest that the hepatotoxicity of ZEN in HepG2 cells is related to ER stress, particularly at a high concentration of ZEN (i.e., $40 \mu \mathrm{g} / \mathrm{mL}$ ).

\section{Conclusions}

In conclusion, our findings demonstrated that ZEN can induce cell death (i.e., apoptosis), oxidative stress, ER stress, and autophagy in human liver cells. In addition, cells exposed to high concentrations of ZEN (e.g., $40 \mu \mathrm{g} / \mathrm{mL}$ ) were revealed to have a decrease in the protein levels of the phase I/II xenobiotic enzymes, which may impact on the endogenous metabolism of mycotoxins. 


\section{Materials and Methods}

\subsection{Chemicals and Reagents}

Dulbecco's modified Eagle's medium (DMEM), fetal bovine serum (FBS), trypsin, and penicillin/streptomycin were obtained from Welgene Inc. (Daegu, Korea). Phosphate buffered saline (PBS) was purchased from Lonza (Walkersville, MD, USA). ZEN was purchased from Cayman Chemical Company (Ann Arbor, MI, USA). Dimethyl sulfoxide (DMSO) and trypan blue solution were purchased from Amresco (Solon, OH, USA). 4-PBA and DCFH-DA were purchased from Sigma (St. Louis, MO, USA). DHE was obtained from Invitrogen (Carlsbad, CA, USA).

\subsection{Cell Culture and Treatments}

The human liver cell line, HepG2, was maintained in DMEM supplemented with 10\% FBS and penicillin/streptomycin in a humidified atmosphere containing $5 \% \mathrm{CO}_{2}$ at $37^{\circ} \mathrm{C}$. Cells were grown to approximately $70 \%$ confluence and synchronized overnight in medium containing $1 \%$ FBS before treatment. Cells were treated with ZEN up to $40 \mu \mathrm{g} / \mathrm{mL}$ for different time lengths. To observe the effect of ER stress, cells were cultured with the ER stress inhibitor, 4-PBA, for $6 \mathrm{~h}$; this was followed by media change and treatment with ZEN (20 and $40 \mu \mathrm{g} / \mathrm{mL})$.

\subsection{Cell Viability Assay}

Cell viability was determined using the trypan blue dye exclusion test. Cells were seeded in 6-well plates and then treated with $\operatorname{ZEN}(0,1,5,10,20$, and $40 \mu \mathrm{g} / \mathrm{mL})$ for $24 \mathrm{~h}$. The number of viable cells was manually counted using a hemocytometer (Hausser Scientific, Horsham, PA, USA).

\subsection{Analysis of Cell Apoptosis}

The ratio of cell apoptosis was analyzed using an annexin V-FITC apoptosis detection kit (Koma Biotech, Seoul, Korea) according to the manufacturer's protocol. Cells were treated with ZEN for $24 \mathrm{~h}$ and washed with PBS after the cell medium, including floating cells, was collected. The attached cells were trypsinized, and the collected cells were washed with serum-containing medium and cold PBS. Cells were then resuspended in $500 \mu \mathrm{L}$ binding buffer, followed by the addition of $1.25 \mu \mathrm{L}$ annexin V-FITC (final concentration, $0.5 \mu \mathrm{g} / \mathrm{mL}$ ) and incubation for $15 \mathrm{~min}$ in the dark. After washing with binding buffer, $10 \mu \mathrm{L}$ PI was added (final concentration, $0.6 \mu \mathrm{g} / \mathrm{mL}$ ) and cells were immediately examined using a CytoFLEX flow cytometer (Beckman Coulter, Indianapolis, IN, USA). In each treatment group, 10,000 cells were counted, and the ratio of apoptosis was analyzed using the CytExpert software (Beckman Coulter, Indianapolis, IN, USA). Four types of cell populations were detected in a dot plot of annexin V-FITC/PI staining: live cells (annexin V-/PI-), early apoptotic cells (annexin V+/PI-), late apoptotic or necrotic cells (annexin V+/PI+), and necrotic cells (annexin V-/PI+).

\subsection{Assessment of ROS Levels}

Intracellular ROS production was measured using DCFH-DA as described previously [55]. Briefly, HepG2 cells were grown to confluence in 6-well plates and treated with ZEN for 2 h. Following treatment, cells were incubated with a final concentration of $10 \mu \mathrm{M}$ DCFH-DA for $30 \mathrm{~min}$. After two rounds of washing with cold PBS, the production of $\mathrm{ROS}\left(\mathrm{H}_{2} \mathrm{O}_{2}\right)$ was visualized using an Olympus IX71 fluorescence microscope and images were digitally captured with an Olympus DP71 camera and DP controller software (Olympus Optical Co., Ltd, Tokyo, Japan). To measure the production of intracellular superoxide anion, HepG2 cells were treated with ZEN for $2 \mathrm{~h}$. The cells were then incubated with a fluorogenic dye, DHE (1 $\mu \mathrm{M}, 30 \mathrm{~min})$, followed by cold PBS washes. The cells on coverslips were fixed with $4 \%$ formaldehyde and visualized with a super-resolution confocal laser scanning microscope (Carl Zeiss Co., Ltd, Oberkochen, Germany). Quantification of DCFH-DA 
positive area (green fluorescence) and DHE positive area (red fluorescence) was conducted using Image J software (National Institute of Health, Bethesda, MD, USA) and graphically presented.

\subsection{Preparation of Cell Lysate, SDS-PAGE, and Western Blot Analysis}

Cells were lysed in RIPA buffer containing $50 \mathrm{mM}$ Tris (pH 8.0), $150 \mathrm{mM} \mathrm{NaCl}, 1 \%$ Triton X-100, $0.5 \%$ sodium deoxycholate, $0.1 \%$ SDS, and a protease inhibitor mixture $(2 \mu \mathrm{g} / \mathrm{mL}$ aprotinin, $10 \mu \mathrm{g} / \mathrm{mL}$ leupeptin, $1 \mathrm{mM}$ PMSF, $5 \mathrm{mM}$ EDTA, $1 \mathrm{mM}$ EGTA, $10 \mathrm{mM}$ sodium fluoride, and $1 \mathrm{mM}$ sodium orthovanadate). Cell lysates were collected by scraping the culture dishes and centrifuging the samples at $21,000 \times g$ for $20 \mathrm{~min}$ at $4{ }^{\circ} \mathrm{C}$. The supernatants were collected and the protein concentration was analyzed with a BCA protein assay kit (Sigma-Aldrich, St. Louis, MO, USA). Protein samples were stored at $-80^{\circ} \mathrm{C}$ until use. For Western blot analysis, protein samples $(40 \mu \mathrm{g} / \mathrm{mL})$ were separated using SDS-PAGE and subsequently transferred onto nitrocellulose membranes. Membranes were then blocked with $3 \%$ non-fat milk buffer for $1 \mathrm{~h} 30 \mathrm{~min}$ at room temperature, followed by incubation with primary antibodies overnight at $4{ }^{\circ} \mathrm{C}$. The primary antibodies included GRP78 (ADI-SPA-826, Enzo Life Sciences, Farmingdale, NY, USA; 1:1000), eIF2 $\alpha$ (\#5324, Cell Signaling Technology, Danvers, MA, USA; 1:2000), phospho-eIF2 $\alpha$ (\#3398, Cell Signaling Technology; 1:1000), LC3 (NB600-1384, Novus Biologicals, Littleton, CO, USA; 1:10000), glyceraldehyde 3-phosphate dehydrogenase (GAPDH) (\#ABS-16, Merck, Darmstadt, Germany; 1:20000), CYP3A4 (BML-CR3340, Enzo Life Sciences; 1:20000), Nrf2 (sc-722, Santa Cruz Biotechnology, Santa Cruz, CA, USA; 1:2000), and proliferating cell nuclear antigen (PCNA; sc-7907, Santa Cruz Biotechnology; 1:5000). After washing, membranes were incubated with secondary antibodies conjugated with horseradish peroxidase for $1 \mathrm{~h}$ at room temperature and visualized using ECL detection reagents (Thermo Scientific, Waltham, MA, USA). The density of the bands was analyzed using Image J software and normalized to the housekeeping proteins.

\subsection{Nuclear Fractionation}

Cells were seeded in a 10-cm dish and treated with ZEN for $6 \mathrm{~h}$. Cells were lysed in hypotonic buffer solution (20 mM Tris ( $\mathrm{pH} 7.4), 10 \mathrm{mM} \mathrm{NaCl}, 3 \mathrm{mM} \mathrm{MgCl} 2$ ) containing a protease inhibitor mixture. After the addition of $10 \%$ Triton X-100, cell lysates were centrifuged at $650 \times \mathrm{g}$ for $10 \mathrm{~min}$ at $4{ }^{\circ} \mathrm{C}$. Pellets were resuspended in cell extraction buffer $(100 \mathrm{mM}$ Tris (pH 7.4), $100 \mathrm{mM} \mathrm{NaCl}$, $1 \%$ Triton X-100, $10 \%$ glycerol, $0.1 \%$ SDS) containing a protease inhibitor mixture. The homogenates were centrifuged at $14,000 \times g$ for $30 \mathrm{~min}$ at $4{ }^{\circ} \mathrm{C}$. Pellets were collected as a cytosolic fraction and the supernatants were collected as the nuclear fraction. Aliquots of cytosolic and nuclear fractions were stored at $-80^{\circ} \mathrm{C}$ until use.

\subsection{RNA Extraction, Reverse Transcription, and Quantitative Real-Time Polymerase Chain Reaction (qRT-PCR)}

Total RNAs were extracted using TRI reagent according to the manufacturer's protocol (Life Technologies, Gaithersburg, MD, USA). The concentration and purity of the RNA were measured as described previously [56]. Total RNA $(2 \mu \mathrm{g})$ was reverse transcribed by reverse transcription-PCR in a final volume of $20 \mu \mathrm{L}$ using the TOPscript ${ }^{\mathrm{TM}}$ RT DryMIX kit (Enzynomics, Daejeon, Korea) according to the manufacturer's protocol. Incubation was performed at $37^{\circ} \mathrm{C}$ for $5 \mathrm{~min}, 50^{\circ} \mathrm{C}$ for $60 \mathrm{~min}$, and $95{ }^{\circ} \mathrm{C}$ for $5 \mathrm{~min}$. The synthesized cDNA was stored at $-80^{\circ} \mathrm{C}$ until use. qRT-PCR was performed on three biological replicates and technical duplicates/triplicates of each cDNA sample with the PikoReal 96 real-time PCR system (Thermo Scientific, Waltham, MA, USA) using the following primers: CHOP: forward primer: 5'-GCG CAT GAA GGA GAA AGA AC-3', reverse primer: 5'-TCA CCA TTC GGT CAA TCA GA-3'; beclin1: forward primer: 5'-CAT GCT CTG GCC AAT AAG ATG GGT-3' ${ }^{\prime}$, reverse primer: 5'-CGG CAG CTC CTT AGA TTT GTC TGT-3'; LC3-II: forward primer: 5'-GAG AAG CAG CTT CCT GTT CTG G-3' , reverse primer: 5'-GTG TCC GTT CAC CAA CAG GAA G-3'; PXR: forward primer: 5'-GCT GGA ACC ATG CTG ACT TTG T-3', reverse primer: 5' -AAG TGA TAG CCA GTG GCC TTG T-3'; CYP3A4: forward primer: 5'-TCT TCA CCG TGA CCC AAA GTA CTG-3' ${ }^{\prime}$, reverse primer: 5'-AGC AAA CCT CAT GCC AAT GCA G-3'; UGT1A: forward primer: 5'-CCT TGG ACG 
TGA TTG GTT TCC TCT-3' ${ }^{\prime}$, reverse primer: $5^{\prime}$-GGG TCT TGG ATT TGT GGG CTT TCT-3' ; GAPDH: forward primer: 5'-GAC CCC TTC ATT GAC CTC AAC TAC-3', reverse primer: $5^{\prime}$-ATG ACA AGC TTC CCG TTC TCA G-3'. Each PCR solution (total volume of $20 \mu \mathrm{L}$ ) consisted of $1 \mu \mathrm{L}$ of cDNA sample, $0.5 \mu \mathrm{L}$ each of $10 \mu \mathrm{M}$ forward and reverse primer, $10 \mu \mathrm{L}$ of $2 \times$ Real-Time PCR Smart mix (SolGent, Daejeon, Korea), and $8 \mu \mathrm{L}$ of RNase-free water. The cycling conditions included a denaturation step at $95{ }^{\circ} \mathrm{C}$ for $15 \mathrm{~min}$, followed by $40 \mathrm{PCR}$ cycles at $95^{\circ} \mathrm{C}$ for $20 \mathrm{~s}$ and $60^{\circ} \mathrm{C}$ for $40 \mathrm{~s}$. A melting curve analysis was performed at the end of each PCR program to exclude nonspecific product formation. Real-time fluorescence measurements were carried out every cycle and the change in the threshold cycle $(\Delta \mathrm{Ct})$ was calculated. The mRNA levels of each sample were quantified using the $2^{-\Delta \Delta \mathrm{Ct}}$ method and normalized using GAPDH gene, which served as the endogenous control.

\subsection{Statistical Analysis}

All experiments were repeated at least three times. Data are expressed as mean \pm standard error of the mean (SEM). Statistical significance was determined with SPSS-PASW statistics software version 18.0 for Windows (SPSS, Chicago, IL, USA) by one-way ANOVA and groups were compared using Tukey's test. A $p$-value less than 0.05 was considered to indicate statistical significance.

Author Contributions: Conceptualization, S.G.H., J.E.Y., and K.Y.L.; investigation, J.E.Y., J.S.S., W.N.C., C.H.J., and H.C.K.; resources, S.G.H., and K.Y.L.; writing-original draft preparation, S.G.H., and J.E.Y.; review and editing, S.G.H., J.E.Y., and H.C.K.; supervision, S.G.H. All authors have read and agreed to the published version of the manuscript.

Funding: This paper was supported by Konkuk University in 2018.

Conflicts of Interest: The authors have declared that no competing interests exist.

\section{References}

1. Sun, L.H.; Lei, M.Y.; Zhang, N.Y.; Gao, X.; Li, C.; Krumm, C.S.; Qi, D.-S. Individual and combined cytotoxic effects of aflatoxin B1, zearalenone, deoxynivalenol and fumonisin B1 on BRL 3A rat liver cells. Toxicon 2015, 95, 6-12. [CrossRef] [PubMed]

2. Lai, F.N.; Ma, J.Y.; Liu, J.C.; Wang, J.J.; Cheng, S.F.; Sun, X.F.; Li, L.; Li, B.; Nyachoti, C.M.; Shen, W. The influence of $\mathrm{N}$-acetyl-l-cysteine on damage of porcine oocyte exposed to zearalenone in vitro. Toxicol. Appl. Pharmacol. 2015, 289, 341-348. [CrossRef] [PubMed]

3. Hueza, I.M.; Raspantini, P.C.F.; Raspantini, L.E.R.; Latorre, A.O.; Górniak, S.L. Zearalenone, an estrogenic mycotoxin, is an immunotoxic compound. Toxins 2014, 6, 1080-1095. [CrossRef] [PubMed]

4. Zhang, R.Q.; Sun, X.F.; Wu, R.Y.; Cheng, S.F.; Zhang, G.L.; Zhai, Q.Y.; Liu, X.L.; Zhao, Y.; Shen, W.; Li, L. Zearalenone exposure elevated the expression of tumorigenesis genes in mouse ovarian granulosa cells. Toxicol. Appl. Pharmacol. 2018, 356, 191-203. [CrossRef]

5. Sun, L.H.; Lei, M.Y.; Zhang, N.Y.; Zhao, L.; Krumm, C.S.; Qi, D.S. Hepatotoxic effects of mycotoxin combinations in mice. Food Chem. Toxicol. 2014, 74, 289-293. [CrossRef]

6. Gazzah, A.C.; Bennour, E.E.G.; Bouaziz, C.; Abid, S.; Ladjimi, M.; Bacha, H. Sequential events of apoptosis induced by zearalenone in cultured hepatocarcinoma cells. Mycotoxin Res. 2010, 26, 187-197. [CrossRef]

7. Grant, D. Detoxification pathways in the liver. In Journal of Inherited Metabolic Disease; Springer: Berlin/Heidelberg, Germany, 1991; pp. 421-430. [CrossRef]

8. Iyanagi, T. Molecular mechanism of phase I and phase II drug-metabolizing enzymes: Implications for detoxification. Int. Rev. Cytol. 2007, 260, 35-112. [CrossRef]

9. Zanger, U.M.; Schwab, M. Cytochrome P450 enzymes in drug metabolism: Regulation of gene expression, enzyme activities, and impact of genetic variation. Pharmacol. Ther. 2013, 138, 103-141. [CrossRef]

10. Wang, Y.M.; Lin, W.; Chai, S.C.; Wu, J.; Ong, S.S.; Schuetz, E.G.; Chen, T. Piperine activates human pregnane $\mathrm{X}$ receptor to induce the expression of cytochrome P450 3A4 and multidrug resistance protein 1. Toxicol. Appl. Pharmacol. 2013, 272, 96-107. [CrossRef]

11. Zhang, Q.; Pi, J.; Woods, C.G.; Andersen, M.E. Phase I to II cross-induction of xenobiotic metabolizing enzymes: A feedforward control mechanism for potential hormetic responses. Toxicol. Appl. Pharmacol. 2009, 237, 345-356. [CrossRef] 
12. Döring, B.; Petzinger, E. Phase 0 and phase III transport in various organs: Combined concept of phases in xenobiotic transport and metabolism. Drug Metab. Rev. 2014, 46, 261-282. [CrossRef] [PubMed]

13. Banerjee, S.; Ghosh, J.; Sil, P. Drug metabolism and oxidative stress: Cellular mechanism and new therapeutic insights. Biochem. Anal. Biochem. 2016, 5, 2161-1009. [CrossRef]

14. Cao, S.S.; Kaufman, R.J. Endoplasmic reticulum stress and oxidative stress in cell fate decision and human disease. Antioxid. Redox Signal. 2014, 21, 396-413. [CrossRef] [PubMed]

15. Navid, F.; Colbert, R.A. Causes and consequences of endoplasmic reticulum stress in rheumatic disease. Nat. Rev. Rheumatol. 2017, 13, 25. [CrossRef] [PubMed]

16. Tabas, I.; Ron, D. Integrating the mechanisms of apoptosis induced by endoplasmic reticulum stress. Nat. Cell Biol. 2011, 13, 184. [CrossRef]

17. Rashid, H.O.; Yadav, R.K.; Kim, H.R.; Chae, H.J. ER stress: Autophagy induction, inhibition and selection. Autophagy 2015, 11, 1956-1977. [CrossRef]

18. Ogata, M.; Hino, S.I.; Saito, A.; Morikawa, K.; Kondo, S.; Kanemoto, S.; Murakami, T.; Taniguchi, M.; Tanii, I.; Yoshinaga, K. Autophagy is activated for cell survival after endoplasmic reticulum stress. Mol. Cell. Biol. 2006, 26, 9220-9231. [CrossRef]

19. Milićević, D.R.; Škrinjar, M.; Baltić, T. Real and perceived risks for mycotoxin contamination in foods and feeds: Challenges for food safety control. Toxins 2010, 2, 572-592. [CrossRef]

20. Avantaggiato, G.; Solfrizzo, M.; Visconti, A. Recent advances on the use of adsorbent materials for detoxification of Fusarium mycotoxins. Food Addit. Contam. 2005, 22, 379-388. [CrossRef]

21. Afsah-Hejri, L.; Jinap, S.; Hajeb, P.; Radu, S.; Shakibazadeh, S. A review on mycotoxins in food and feed: Malaysia case study. Compr. Rev. Food Sci. Food Saf. 2013, 12, 629-651. [CrossRef]

22. Chen, F.; Li, Q.; Zhang, Z.; Lin, P.; Lei, L.; Wang, A.; Jin, Y. Endoplasmic reticulum stress cooperates in zearalenone-induced cell death of RAW 264.7 macrophages. Int. J. Mol. Sci. 2015, 16, 19780-19795. [CrossRef] [PubMed]

23. Yu, J.Y.; Zheng, Z.H.; Son, Y.O.; Shi, X.; Jang, Y.O.; Lee, J.C. Mycotoxin zearalenone induces AIF-and ROS-mediated cell death through p53-and MAPK-dependent signaling pathways in RAW264. 7 macrophages. Toxicol. In Vitro 2011, 25, 1654-1663. [CrossRef] [PubMed]

24. Fan, W.; Shen, T.; Ding, Q.; Lv, Y.; Li, L.; Huang, K.; Yan, L.; Song, S. Zearalenone induces ROS-mediated mitochondrial damage in porcine IPEC-J2 cells. J. Biochem. Mol. Toxicol. 2017, 31, e21944. [CrossRef]

25. Tatay, E.; Espín, S.; García-Fernández, A.J.; Ruiz, M.J. Oxidative damage and disturbance of antioxidant capacity by zearalenone and its metabolites in human cells. Toxicol. In Vitro 2017, 45, 334-339. [CrossRef] [PubMed]

26. Li, Y.; Zhang, B.; He, X.; Cheng, W.H.; Xu, W.; Luo, Y.; Liang, R.; Luo, H.; Huang, K. Analysis of individual and combined effects of ochratoxin A and zearalenone on HepG2 and KK-1 cells with mathematical models. Toxins 2014, 6, 1177-1192. [CrossRef]

27. Zheng, W.-L.; Wang, B.-J.; Wang, L.; Shan, Y.-P.; Zou, H.; Song, R.-L.; Wang, T.; Gu, J.-H.; Yuan, Y.; Liu, X.-Z. ROS-mediated cell cycle arrest and apoptosis induced by zearalenone in mouse Sertoli cells via ER stress and the ATP/AMPK pathway. Toxins 2018, 10, 24. [CrossRef]

28. Guo, H.L.; Hassan, H.M.; Ding, P.P.; Wang, S.J.; Chen, X.; Wang, T.; Sun, L.X.; Zhang, L.Y.; Jiang, Z.Z. Pyrazinamide-induced hepatotoxicity is alleviated by 4-PBA via inhibition of the PERK-eIF2 $\alpha$-ATF4-CHOP pathway. Toxicology 2017, 378, 65-75. [CrossRef]

29. Dara, L.; Ji, C.; Kaplowitz, N. The contribution of endoplasmic reticulum stress to liver diseases. Hepatology 2011, 53, 1752-1763. [CrossRef]

30. Jiang, H.Y.; Wek, R.C. Phosphorylation of eIF2 $\alpha$ reduces protein synthesis and enhances apoptosis in response to proteasome inhibition. J. Biol. Chem. 2005. [CrossRef]

31. Sun, Q.; Zhong, W.; Zhang, W.; Li, Q.; Sun, X.; Tan, X.; Sun, X.; Dong, D.; Zhou, Z. Zinc deficiency mediates alcohol-induced apoptotic cell death in the liver of rats through activating ER and mitochondrial cell death pathways. Am. J. Physiol. Gastrointest. Liver Physiol. 2015, 308, G757-G766. [CrossRef]

32. Xiao, Y.; Xu, S.; Zhao, S.; Liu, K.; Lu, Z.; Hou, Z. Protective effects of selenium against zearalenone-induced apoptosis in chicken spleen lymphocyte via an endoplasmic reticulum stress signaling pathway. Cell Stress Chaperones 2019, 24, 77-89. [CrossRef] [PubMed]

33. Oyadomari, S.; Mori, M. Roles of CHOP/GADD153 in endoplasmic reticulum stress. Cell Death Differ. 2004, 11, 381. [CrossRef] [PubMed] 
34. Iurlaro, R.; Muñoz-Pinedo, C. Cell death induced by endoplasmic reticulum stress. FEBS J. 2016, 283, 2640-2652. [CrossRef] [PubMed]

35. Salem, I.B.; Prola, A.; Boussabbeh, M.; Guilbert, A.; Bacha, H.; Abid-Essefi, S.; Lemaire, C. Crocin and Quercetin protect HCT116 and HEK293 cells from Zearalenone-induced apoptosis by reducing endoplasmic reticulum stress. Cell Stress Chaperones 2015, 20, 927-938. [CrossRef]

36. Kouroku, Y.; Fujita, E.; Tanida, I.; Ueno, T.; Isoai, A.; Kumagai, H.; Ogawa, S.; Kaufman, R.; Kominami, E.; Momoi, T. ER stress (PERK/eIF2 $\alpha$ phosphorylation) mediates the polyglutamine-induced LC 3 conversion, an essential step for autophagy formation. Cell Death Differ. 2007, 14, 230. [CrossRef]

37. Kang, R.; Zeh, H.; Lotze, M.; Tang, D. The Beclin 1 network regulates autophagy and apoptosis. Cell Death Differ. 2011, 18, 571. [CrossRef]

38. Tanida, I.; Minematsu-Ikeguchi, N.; Ueno, T.; Kominami, E. Lysosomal turnover, but not a cellular level, of endogenous LC3 is a marker for autophagy. Autophagy 2005, 1, 84-91. [CrossRef]

39. Gu, X.; Han, D.; Chen, W.; Zhang, L.; Lin, Q.; Gao, J.; Fanning, S.; Han, B. SIRT1-mediated FoxOs pathways protect against apoptosis by promoting autophagy in osteoblast-like MC3T3-E1 cells exposed to sodium fluoride. Oncotarget 2016, 7, 65218. [CrossRef]

40. Jiang, W.; Zhang, X.; Hao, J.; Shen, J.; Fang, J.; Dong, W.; Wang, D.; Zhang, X.; Shui, W.; Luo, Y. SIRT1 protects against apoptosis by promoting autophagy in degenerative human disc nucleus pulposus cells. Sci. Rep. 2014, 4, 7456. [CrossRef]

41. Mariño, G.; Niso-Santano, M.; Baehrecke, E.H.; Kroemer, G. Self-consumption: The interplay of autophagy and apoptosis. Nat. Rev. Mol. Cell Biol. 2014, 15, 81. [CrossRef]

42. Wang, Y.; Zheng, W.; Bian, X.; Yuan, Y.; Gu, J.; Liu, X.; Liu, Z.; Bian, J. Zearalenone induces apoptosis and cytoprotective autophagy in primary Leydig cells. Toxicol. Lett. 2014, 226, 182-191. [CrossRef] [PubMed]

43. Zheng, W.; Wang, B.; Si, M.; Zou, H.; Song, R.; Gu, J.; Yuan, Y.; Liu, X.; Zhu, G.; Bai, J. Zearalenone altered the cytoskeletal structure via ER stress-autophagy-oxidative stress pathway in mouse TM4 Sertoli cells. Sci. Rep. 2018, 8, 3320. [CrossRef] [PubMed]

44. Shen, T.; Miao, Y.; Ding, C.; Fan, W.; Liu, S.; Lv, Y.; Gao, X.; De Boevre, M.; Yan, L.; Okoth, S.; et al. Activation of the p38/MAPK pathway regulates autophagy in response to the CYPOR-dependent oxidative stress induced by zearalenone in porcine intestinal epithelial cells. Food Chem. Toxicol. 2019, 131, 110527. [CrossRef] [PubMed]

45. Kowalska, K.; Habrowska-Górczyńska, D.E.; Piastowska-Ciesielska, A.W. Zearalenone as an endocrine disruptor in humans. Environ. Toxicol. Pharmacol. 2016, 48, 141-149. [CrossRef] [PubMed]

46. Pfeiffer, E.; Hildebrand, A.; Damm, G.; Rapp, A.; Cramer, B.; Humpf,H.U.; Metzler, M. Aromatic hydroxylation is a major metabolic pathway of the mycotoxin zearalenone in vitro. Mol. Nutr. Food Res. 2009, 53, 1123-1133. [CrossRef] [PubMed]

47. Ayed-Boussema, I.; Pascussi, J.M.; Maurel, P.; Bacha, H.; Hassen, W. Zearalenone activates pregnane X receptor, constitutive androstane receptor and aryl hydrocarbon receptor and corresponding phase I target genes mRNA in primary cultures of human hepatocytes. Environ. Toxicol. Pharmacol. 2011, 31, 79-87. [CrossRef] [PubMed]

48. Puatanachokchai, R.; Morimura, K.; Wanibuchi, H.; Oka, M.; Kinoshita, A.; Mitsuru, F.; Yamaguchi, S.; Funae, Y.; Fukushima, S. Alpha-benzene hexachloride exerts hormesis in preneoplastic lesion formation of rat hepatocarcinogenesis with the possible role for hepatic detoxifying enzymes. Cancer Lett. 2006, 240, 102-113. [CrossRef]

49. Koromilas, A.E. Roles of the translation initiation factor eIF $2 \alpha$ serine 51 phosphorylation in cancer formation and treatment. Biochim. Biophys. Acta Gene Regul. Mech. 2015, 1849, 871-880. [CrossRef]

50. Shi, B.; Su, Y.; Chang, S.; Sun, Y.; Meng, X.; Shan, A. Vitamin C protects piglet liver against zearalenone-induced oxidative stress by modulating expression of nuclear receptors PXR and CAR and their target genes. Food Funct. 2017, 8, 3675-3687. [CrossRef]

51. Amantini, C.; Farfariello, V.; Cardinali, C.; Morelli, M.B.; Marinelli, O.; Nabissi, M.; Santoni, M.; Bonfili, L.; Cecarini, V.; Eleuteri, A.M. The TRPV1 ion channel regulates thymocyte differentiation by modulating autophagy and proteasome activity. Oncotarget 2017, 8, 90766. [CrossRef]

52. Carlisle, R.E.; Brimble, E.; Werner, K.E.; Cruz, G.L.; Ask, K.; Ingram, A.J.; Dickhout, J.G. 4-Phenylbutyrate inhibits tunicamycin-induced acute kidney injury via CHOP/GADD153 repression. PLoS ONE 2014, 9, e84663. [CrossRef] [PubMed] 
53. Yan, S.; Zhang, H.; Wang, J.; Zheng, F.; Dai, J. Perfluorooctanoic acid exposure induces endoplasmic reticulum stress in the liver and its effects are ameliorated by 4-phenylbutyrate. Free Radic. Biol. Med. 2015, 87, 300-311. [CrossRef] [PubMed]

54. Ma, L.; Chu, W.; Chai, J.; Shen, C.; Li, D.; Wang, X. ER stress and subsequent activated calpain play a pivotal role in skeletal muscle wasting after severe burn injury. PLoS ONE 2017, 12, e0186128. [CrossRef] [PubMed]

55. Seok, J.S.; Jeong, C.H.; Petriello, M.C.; Seo, H.G.; Yoo, H.; Hong, K.; Han, S.G. Piperlongumine decreases cell proliferation and the expression of cell cycle-associated proteins by inhibiting Akt pathway in human lung cancer cells. Food Chem. Toxicol. 2018, 111, 9-18. [CrossRef] [PubMed]

56. Lin, P.; Lan, X.; Chen, F.; Yang, Y.; Jin, Y.; Wang, A. Reference gene selection for real-time quantitative PCR analysis of the mouse uterus in the peri-implantation period. PLOS ONE 2013, 8, e62462. [CrossRef]

(C) 2019 by the authors. Licensee MDPI, Basel, Switzerland. This article is an open access article distributed under the terms and conditions of the Creative Commons Attribution (CC BY) license (http://creativecommons.org/licenses/by/4.0/). 